\title{
The impact of technical failures during cultivation of an inclusion body process
}

\author{
Alexander Pekarsky $^{1}$ (D) $\cdot$ Vanessa Konopek $^{1} \cdot$ Oliver Spadiut $^{1}[$
}

Received: 15 April 2019 / Accepted: 4 June 2019 / Published online: 2 July 2019

(c) The Author(s) 2019

\begin{abstract}
In biotechnological processes, technical failures in the upstream process often lead to batch loss. It is of great interest to investigate the empirical impact of technical failures to understand and mitigate their impact accurately and reduce economic damage. We investigated the impact in the upstream and downstream of a recombinant antibody fragment inclusion body production process chain to provide integrated empirical data and knowledge. First, we provided a reproducible process chain that yielded high inclusion body content, high specific product titer, and a refolding yield of $30 \%$. The inclusion body downstream proved to be of high reproducibility. Through the intended introduction of technical failures, we were not only able to shed more light on the empirical responses in the upstream and downstream, but also on process-boosting parameters that would have been neglected. Herein, a short increase in temperature during the cultivation clearly increased the refolding yield.
\end{abstract}

Keywords Inclusion body $\cdot$ Technical failure $\cdot$ Escherichia coli $\cdot$ Upstream process $\cdot$ Downstream process

\section{Introduction}

Process design and development for new recombinant proteins is often complex, especially when therapeutic use is targeted. The United States' Food and Drug Administration (FDA) has recognized the requirement for stricter risk-based controls during drug manufacturing processes. Therefore, an important initiative, entitled "Pharmaceutical cGMPs for the 21st Century: A Risk-Based Approach", was launched in 2002. Shortly after, the "Process Analytical Technology" (PAT) followed that comprises recommendations to improve process understanding and analysis [1]. The FDA

Electronic supplementary material The online version of this article (https://doi.org/10.1007/s00449-019-02158-x) contains supplementary material, which is available to authorized users.

Oliver Spadiut

oliver.spadiut@tuwien.ac.at

Alexander Pekarsky

alexander.pekarsky@tuwien.ac.at

Vanessa Konopek

vanessa@konopek.eu

1 Institute of Chemical, Environmental and Bioscience Engineering, Research Area Biochemical Engineering, Technische Universität Wien, Gumpendorfer Strasse 1a, 1060 Vienna, Austria emphasizes that it is important to ensure high and robust product quality by real-time measurements and online monitoring, which also underlines that quality should not only be tested, but it should be built in. Later, the International Council for Harmonisation of Technical Requirements for Pharmaceuticals for Human Use (I.C.H.) released three fundamental frameworks: "Q8 Pharmaceutical Development" [2]; "Q9 Quality Risk Management" [3]; "Q10 Pharmaceutical Quality System" [4]. This resulted in the introduction of the "Quality by Design" $(\mathrm{QbD})$ approach, released by the FDA together with the EMA (European Medicines Agency) [5-7]. QbD is a proactive and systematic approach for product and process development that is important to understand interconnections between product and process and minimizes risks using multivariate methods [8]. It requires the identification of a design and control space, in which the influence of known variations in critical process parameters (CPPs) on critical quality attributes (CQAs) or key performance indicators (KPIs) is understood [7].

Biotechnological processes are performed with technological equipment and sophisticated software tools [9]. Although process control, automation, and simulation are widely applied for biotechnological processes, several risks cannot be anticipated or are often tolerated if their probability of occurrence is below a given threshold (e.g., based on Failure Mode and Effects Analysis). Hardware- or 
software-based errors and also human-based errors can affect each unit operation in a biotechnological production process chain, which can lead to major deviations in product quantity and quality and even up to process termination [10, 11]. Thus, data-driven approaches for technical failures and process fault detection as also decision matrices are often implemented in standard biopharmaceutical processes [10, 11]. Due to insufficient knowledge or risk-based precautions, technical failures and process faults can often lead to process termination and batch loss. We believe that it is of great interest to investigate the empirical impact of technical failures on bioprocesses to understand and mitigate their impact accurately. Furthermore, this knowledge can help to avoid economic damage through batch loss. Technical failures can arise from numerous malfunctions during the upstream processing (USP). Some examples, their origin, and their impact are shown in Table 1 for the production of inclusion bodies (IBs) in Escherichia coli. The given examples were brought together from experiences in our research group and expert knowledge. IBs are formed in the cytosol of $E$. coli and they usually consist of aggregated, insoluble target protein that is misfolded or partially unfolded, leading to no or reduced activity $[12,13]$. Their formation is mostly dependent on the used promoter system and strength [14], the target protein class [12], and the process conditions $[15,16]$. However, the misfolded/unfolded character of IBs makes formation kinetics, size distributions in the cytosol, and IB purity comparable between similar protein classes (e.g., $[15,17])$ until the initial IB solubilisation procedure, in which protein specific conditions have to be considered.

Table 1 Technical failures in the upstream processing, their origin and impact on the bioprocess, the E. coli cell, and the inclusion bodies

\begin{tabular}{|c|c|c|c|c|}
\hline Technical failures & Origin & Impact on bioprocess & Impact on cell & Impact on IB \\
\hline Interruption of aeration & $\begin{array}{l}\text { Inlet filter blocked } \\
\text { Outlet filter blocked } \\
\text { Gas mixer defect }\end{array}$ & $\begin{array}{l}\text { No aeration } \\
\text { Decrease in } \mathrm{dO}_{2} \\
\text { No offgas analysis } \\
\text { Headspace pressure not } \\
\quad \text { controllable } \\
\text { Decreased mixing (if stir- } \\
\quad \text { rer is interconnected) } \\
\text { Acidification of medium } \\
\text { (organic acids) }\end{array}$ & $\begin{array}{l}\text { Switch to anaerobic } \\
\text { metabolism } \\
\text { (e.g., }[18,19]) \\
\text { Formation of organic acids } \\
\text { and ethanol (growth } \\
\text { decrease) } \\
\text { (e.g., }[18,20]) \\
\text { Cellular stress }\end{array}$ & $\begin{array}{l}\text { Decreased product forma- } \\
\text { tion } \\
\text { (e.g., [19]) }\end{array}$ \\
\hline Interruption of feeding & $\begin{array}{l}\text { Feeding tube blocked } \\
\text { Feeding pump defect } \\
\text { Feed tank empty }\end{array}$ & $\begin{array}{l}\text { No substrate } \\
\text { Increase in } \mathrm{dO}_{2} \\
\text { Decrease in offgas } \mathrm{CO}_{2} \\
\text { Increase in offgas } \mathrm{O}_{2}\end{array}$ & $\begin{array}{l}\text { Maintenance metabolism } \\
\text { (e.g., }[21]) \\
\text { No or reduced growth } \\
\text { (e.g., }[21])\end{array}$ & $\begin{array}{l}\text { Decreased product forma- } \\
\text { tion }\end{array}$ \\
\hline Overfeeding & $\begin{array}{l}\text { Feeding pump defect } \\
\text { Feed concentration too } \\
\text { high } \\
\text { Change in feeding param- } \\
\text { eter }\end{array}$ & $\begin{array}{l}\text { Accumulation of substrate } \\
\text { and acetate } \\
\text { Decrease in } \mathrm{dO}_{2} \\
\text { Increase in offgas } \mathrm{CO}_{2} \\
\text { Decrease in offgas } \mathrm{O}_{2} \\
\text { Increased base addition }\end{array}$ & $\begin{array}{l}\text { Increased } \mu \text { and } \mathrm{q}_{\mathrm{S}} \text { over- } \\
\text { flow metabolism (e.g., } \\
[22]) \\
\text { Increased } \mathrm{O}_{2} \text { demand } \\
\text { Cellular stress }\end{array}$ & $\begin{array}{l}\text { Increased product formation } \\
\text { (e.g., [16]) } \\
\text { Decreased product forma- } \\
\text { tion } \\
\text { (overflow metabolism) (e.g., } \\
\text { [19]) }\end{array}$ \\
\hline Failure in $\mathrm{pH}$ control & $\begin{array}{l}\text { Base tube blocked } \\
\text { Base pump defect } \\
\text { pH probe defect }\end{array}$ & $\begin{array}{l}\text { Acidification of medium } \\
\text { Cell dependent change in } \\
\text { offgas signals }\end{array}$ & $\begin{array}{l}\text { Change in metabolism } \\
\text { (e.g., [23]) } \\
\text { Decreased viability and } \\
\quad \text { growth } \\
\text { (e.g., }[23]) \\
\text { Cellular stress }\end{array}$ & $\begin{array}{l}\text { Lower } \mathrm{pH} \text { can improve IB } \\
\text { titer and purity }[15,24] \\
\text { Low } \mathrm{pH} \text { increases IB den- } \\
\text { sity (decreased solubility } \\
\text { in DSP) } \\
\text { (e.g., }[25])\end{array}$ \\
\hline $\begin{array}{l}\text { Failure in temperature } \\
\text { control }\end{array}$ & $\begin{array}{l}\text { Temperature probe defect } \\
\text { Heat exchanger defect }\end{array}$ & $\begin{array}{l}\text { Increase in temperature } \\
\text { Decrease in } \mathrm{dO}_{2} \\
\text { Increase in offgas } \mathrm{CO}_{2} \\
\text { Decrease in offgas } \mathrm{O}_{2}\end{array}$ & $\begin{array}{l}\text { Increased metabolic } \\
\text { activity } \\
\text { (if temperature increases) } \\
\text { Increased probability of } \\
\text { cell lysis or leakiness } \\
\text { (e.g., [26]) } \\
\text { Cellular stress }\end{array}$ & $\begin{array}{l}\text { Impact on IB activity (e.g., } \\
[27,28]) \\
\text { Impact on IB titer } \\
\text { (e.g., }[15,28])\end{array}$ \\
\hline Failure in agitation & $\begin{array}{l}\text { Stirring motor defect } \\
\text { Aeration interrupted (if } \\
\text { stirrer is interconnected) }\end{array}$ & $\begin{array}{l}\text { Decreased mixing } \\
\text { Decrease in } \mathrm{dO}_{2}\end{array}$ & $\begin{array}{l}\text { Decreased substrate/O } \\
\text { availability } \\
\text { Medium heterogeneity } \rightarrow \\
\text { Stress } \\
\text { (e.g., }[18,19,29,30])\end{array}$ & $\begin{array}{l}\text { Decreased product forma- } \\
\text { tion } \\
\text { (e.g., [19]) }\end{array}$ \\
\hline
\end{tabular}

It was assumed that the respective technical failures occur during the induction phase, in which target protein is produced and, therefore, represents the most critical process phase 
In this study, we investigated the impact of common technical failures during the USP on (1) cell physiology of E. coli and (2) the downstream processing (DSP) and impurity of an antibody fragment, produced as intracellular IB product to provide an integrated understanding. Technical failures were manually introduced during the induction phase. We kept the resulting process deviation phase for approximately $1 \mathrm{~h}$, as we expected that period to be required to detect and correct the failure. After that, we allowed the cells to regenerate under standard process conditions for at least another hour, before we analysed the effects. The produced IBs were analysed quantitatively in the DSP unit operations IB wash, IB solubilisation, and IB refolding. We found that technical failures, like presented in Table 1, do not necessarily require process termination and batch loss. Furthermore, our results provide indications that certain technical failures or parameter shifts can even have a positive impact on the IB DSP.

\section{Materials and methods}

\section{Chemicals}

All chemicals were purchased from Carl Roth $\mathrm{GmbH}$ (Vienna, Austria), if not stated otherwise.

\section{Strain and expression}

The gene coding for a recombinant antibody fragment was cloned into the pET-28a(+) vector together with a kanamycin resistance and a stop codon downstream of the target sequence. Then, this target gene containing vector was transformed into an E. coli strain BL21(DE3). Cryo cultures were prepared in $25 \%$ glycerol and used for each fermentation.

\section{IB production process variance}

Bioreactor cultivations are rather reproducible when performed under the same conditions, but IB processing, including all DSP unit operations, requires a high degree of human interaction. Therefore, we performed four parallel verification runs $(\mathrm{C} 1-\mathrm{C} 4)$ to analyse the variance of the whole IB production process chain without the introduction of technical failures. The harvested biomass was disrupted and the IBs underwent the whole DSP. The variance of each parameter or unit operation was expressed as the average absolute error $(\Theta)$ with formula (1) and (2):

average mean $\left(\bar{x}_{\text {ave }}\right)=\frac{\sum_{i=1}^{n} \bar{x}_{i}}{n}$,

$\Theta=\left(\frac{\sum_{i=1}^{n}\left|\bar{x}_{\mathrm{ave}}-\bar{x}_{i}\right|}{n}\right) \times \frac{\bar{x}_{\mathrm{ave}}}{100}$,

$i=$ respective cultivation of $\mathrm{C} 1-\mathrm{C} 4$ ( $n=4$; number of cultivations), and $\bar{x}_{i}=$ calculated average of respective parameter in cultivation $i$.

\section{Upstream process}

Ten cultivations were performed (Table 2). For all cultivations, a preculture was performed. Each bioreactor cultivation was composed of a batch and a non-induced fed-batch phase to generate biomass followed by an induced fed-batch phase (induction phase) to produce the target protein as intracellular IBs.

The preculture medium was prepared according to [31]. Ingredients per litre were: $8.8 \mathrm{~g}$ D-(+)glucose monohydrate, $13.3 \mathrm{~g} \mathrm{KH}_{2} \mathrm{PO}_{4}, 4.0 \mathrm{~g}\left(\mathrm{NH}_{4}\right)_{2} \mathrm{HPO}_{4}, 1.7 \mathrm{~g}$ citric acid, $1.2 \mathrm{~g} \mathrm{MgSO}_{4} \cdot 7 \mathrm{H}_{2} \mathrm{O}, 0.1 \mathrm{~g} \mathrm{Fe}(\mathrm{III})$ citrate, $0.0084 \mathrm{~g}$ EDTA, $0.0130 \mathrm{~g} \mathrm{Zn}\left(\mathrm{CH}_{3} \mathrm{COO}\right)_{2} \cdot 2 \mathrm{H}_{2} \mathrm{O}, 0.0045 \mathrm{~g}$ thiamine $\mathrm{HCl}$, $0.1 \mathrm{~g}$ kanamycin sulphate, and $5 \mathrm{~mL}$ trace-element solution (TE). TE contained the following ingredients per litre:
Table 2 Performed cultivations with and without technical failures

\begin{tabular}{lllll}
\hline Cultivation & Technical failure & Theoretical origin & Real origin & $\begin{array}{l}\text { Total } \\
\text { induction } \\
\text { time }\end{array}$ \\
\hline C1-C4 & Reproducibility runs & & & $8.4 \mathrm{~h}$ \\
C5 & Reference run & & & $8.1 \mathrm{~h}$ \\
C6 & Failure in pH control & e.g., Base pump defect & pH control turned off & $8.1 \mathrm{~h}$ \\
C7 & Failure in $T$ control & e.g., Heat exchanger defect & T control turned off & $8.1 \mathrm{~h}$ \\
C8 & Reference run & & & $11.1 \mathrm{~h}$ \\
C9 & Interruption of feeding & e.g., Empty feed tank & Feed pump stopped & $11.1 \mathrm{~h}$ \\
C10 & Overfeeding & e.g., Wrong feed concentration & Set higher $q_{\mathrm{s}, \text { Glc }}$ & $11.1 \mathrm{~h}$ \\
& & & for feed addition & \\
& & & control & \\
\hline
\end{tabular}


$0.0025 \mathrm{~g} \mathrm{CoCl}_{2} \cdot 6 \mathrm{H}_{2} \mathrm{O}, 0.0150 \mathrm{~g} \mathrm{MnCl}_{2} \cdot 4 \mathrm{H}_{2} \mathrm{O}, 0.0012 \mathrm{~g}$ $\mathrm{CuCl}_{2} \cdot 2 \mathrm{H}_{2} \mathrm{O}, 0.0030 \mathrm{~g} \mathrm{H}_{3} \mathrm{BO}_{3}$, and $0.0025 \mathrm{~g} \mathrm{Na}_{2} \mathrm{MoO}_{4} \cdot 2$ $\mathrm{H}_{2} \mathrm{O}$. Each stock was sterilized separately by autoclavation or sterile filtration with a $0.2 \mu \mathrm{m}$ filter. Batch media were similar to the preculture media, but contained $22 \mathrm{~g} \mathrm{~L}^{-1}$ D-(+)glucose monohydrate and $0.1 \mathrm{~g} \mathrm{~L}^{-1}$ Antifoam PPG 2000 (Sigma-Aldrich, Austria). Feed media contained per litre: $400 \mathrm{~g}$ D-(+)glucose monohydrate, $18.18 \mathrm{~g} \mathrm{MgSO}_{4} \cdot 7$ $\mathrm{H}_{2} \mathrm{O}, 0.03636 \mathrm{~g} \mathrm{Fe}(\mathrm{III})$ citrate, $0.01182 \mathrm{~g}$ EDTA, $0.01455 \mathrm{~g}$ $\mathrm{Zn}\left(\mathrm{CH}_{3} \mathrm{COO}\right)_{2} \cdot 2 \mathrm{H}_{2} \mathrm{O}$, and $7.27 \mathrm{~mL}$ TE.

\section{Preculture}

Precultures were performed in shake flasks at $\mathrm{pH} 7.2$ (set with $10 \mathrm{M} \mathrm{NaOH}$ ) for $8-10 \mathrm{~h}$ at $37^{\circ} \mathrm{C}$ and $230 \mathrm{rpm}$ in an Infors HR Multitron shaker (Infors, Bottmingen, Switzerland). The liquid volume was set to $10-20 \%$ of the possible working volume of the shake flask to assure proper aeration.

\section{Batch phase}

Bioreactor cultivations were carried out in the Eppendorf DASGIP parallel $4 \times 2.5 \mathrm{~L}$ working volume bioreactor system (Eppendorf AG, Hamburg, Germany) with a capacity of four vessels simultaneously. The system was equipped with a calibrated EasyFerm Plus $\mathrm{pH}$ probe (Hamilton, Reno, NV, USA) and a fluorescence dissolved oxygen electrode Visiferm DO425 (Hamilton, Reno, NV, USA) for $\mathrm{dO}_{2}$ online measurement. The cultures were aerated with $2.0 \mathrm{vvm}$ dried air and offgas of the cultures was measured using an infrared cell for $\mathrm{CO}_{2}$ and a $\mathrm{ZrO}_{2}$ sensor for $\mathrm{O}_{2}$ concentration (Blue Sens Gas analytics, Herten, Germany). Batch media were inoculated with $10 \%$ of the final batch volumes from the precultures. Batch cultivations were performed at $35{ }^{\circ} \mathrm{C}$, setpoint for $\mathrm{pH}$ was 7.2 (adjusted with $12.5 \% \mathrm{NH}_{4} \mathrm{OH}$ ), $\mathrm{dO}_{2}$ was set above $30 \%$, and a constant agitation speed of $1200 \mathrm{rpm}$. If agitation was not sufficient to hold the $\mathrm{dO}_{2}$ above $30 \%$, pure $\mathrm{O}_{2}$ was mixed with the dried air aeration. The end of the initial batch phase at $35^{\circ} \mathrm{C}$, and therefore, complete glucose consumption was indicated by an increase in $\mathrm{dO}_{2}$, a drop in offgas $\mathrm{CO}_{2}$, and an increase in offgas $\mathrm{O}_{2}$.

\section{Non-induced and induced fed-batch phase}

After the batch phase, the non-induced fed-batch phase started. Again, the temperature was held constant at $35^{\circ} \mathrm{C}$, the $\mathrm{dO}_{2}$ above $30 \%$ and the $\mathrm{pH}$ at 7.2. The feed was added at a specific substrate uptake rate $\left(q_{\mathrm{s}, \text { Glc }}\right)$ of $0.3 \mathrm{~g} \mathrm{~g}^{-1} \mathrm{~h}^{-1}$ and a biomass yield $\left(Y_{\mathrm{X} / \mathrm{S}}\right)$ of $0.4 \mathrm{~g} \mathrm{~g}^{-1}$, based on prior optimization of the cultivation conditions to increase specific product titer (data not shown). The fed-batch phase ran until a dry cell weight (DCW) biomass concentration of approximately $35 \mathrm{~g} \mathrm{~L}^{-1}$ was reached. Prior to induction, the temperature setpoint was set to $30{ }^{\circ} \mathrm{C}$ for optimal induction. The temperature of $30{ }^{\circ} \mathrm{C}$, the $\mathrm{dO}_{2}$ above $30 \%$, and the $\mathrm{pH}$ at 7.2 were held constant during this phase, but not during all deviation phases due to technical failures. The cells were induced by adding a pulse of sterile IPTG to a final concentration of $1 \mathrm{mM}, q_{\mathrm{s}, \text { Glc }}$ was kept at $0.2 \mathrm{~g} \mathrm{~g}^{-1} \mathrm{~h}^{-1}$, and a $Y_{\mathrm{X} / \mathrm{S}}$ of $0.35 \mathrm{~g} \mathrm{~g}^{-1}$ was used for feeding. The total induction time included the standard induction phase, the deviation phase, and the regeneration phase (Table 2).

\section{Introduction of technical failure}

Technical failures were introduced between 4 and $8.4 \mathrm{~h}$ of induction time (Table 2). To assure accurate results, we performed reference cultivations, $\mathrm{C} 5$ and $\mathrm{C} 8$, respectively, to each set of technical failure cultivations $\mathrm{C} 6 / \mathrm{C} 7$ and $\mathrm{C} 9 / \mathrm{C} 10$. The used DASGIP system made it possible to perform each set of cultivations in parallel. As can be seen from the total induction time in Table 2, C8-C10 were cultivated longer than the $\mathrm{C} 1-\mathrm{C} 7$. This longer induction time was based on the respective technical failures. The interruption of feeding and overfeeding was assumed to be classic technical failures that occur in the late or final stages of the induction phase. Especially, overfeeding is usually a problem with increasing induction times, because cellular performance is usually decreasing over time [32]. When no automated closed-loop feed addition is performed, substrate overfeeding is usually present, as the specific substrate uptake rate of $E$. coli decreases [32]. Therefore, the technical failures in $\mathrm{C} 9$ and $\mathrm{C} 10$ were introduced at the usual end of the induction time. Each deviation phase lasted approximately $1 \mathrm{~h}$ and was followed by at least $1 \mathrm{~h}$ of regeneration under standard induction conditions. The duration of the deviation phases were set to approx. $1 \mathrm{~h}$ to mimic the estimated time that is needed from detection to repair of the technical failure.

\section{Sampling strategy}

Samples were taken during the cultivations: at the beginning of the batch; start of non-induced fed-batch; start of induced fed-batch, start of deviation phase; end of deviation phase; during and at the end of the regeneration phase. IBs were harvested and processed at the end of each cultivation.

\section{Sample analysis}

Dry cell weight (DCW) was determined by centrifugation of $5 \mathrm{~mL}$ culture broth $\left(4000 \mathrm{~g}, 4{ }^{\circ} \mathrm{C}, 10 \mathrm{~min}\right)$, washing the pellet once with $5 \mathrm{~mL}$ water, and subsequent drying for $72 \mathrm{~h}$ at $105^{\circ} \mathrm{C}$. Determination was performed in triplicates. $\mathrm{OD}_{600}$ of the culture broth was measured in duplicates using a spectrophotometer (Genesys 20; ThermoFisher Scientific, Vienna, Austria). Protein concentration of cell free 
supernatant was determined at $595 \mathrm{~nm}$ using the Bradford Protein Assay Kit (Bio-Rad Laboratories GmbH, Vienna, Austria) with bovine serum albumin (BSA) (protein standard; micro standard, liquid; P0914; Sigma-Aldrich, Vienna, Austria) as standard. Relative DNA content was measured as absorption at $260 \mathrm{~nm}$ with a NanoDrop-2000 (ThermoFisher Scientific, Vienna, Austria). Concentration of glucose and other metabolites was determined in cell free samples of the bioreactor cultivation by HPLC (Agilent Technologies, Santa Clara, United States) equipped with a Supelco guard column and a Supelco gel C-610H ion-exchange column (Sigma-Aldrich, Vienna, Austria) and a refractive index detector (Agilent Technologies, Santa Clara, United States). The mobile phase was $0.1 \% \mathrm{H}_{3} \mathrm{PO}_{4}$ with a constant flow rate of $0.5 \mathrm{~mL} \mathrm{~min}^{-1}$ and the system was run isocratically. Calibration was done by measuring standard points in the range of $0.1-10 \mathrm{~g} \mathrm{~L}^{-1}$ glucose and metabolites (formate, ethanol, acetate). Along with the observed standard deviations for the measurements of DCW, glucose, and metabolites, the errors were propagated to the specific rates as well as to the yield coefficients.

\section{Downstream process}

\section{Homogenization of broth and isolation of inclusion bodies}

The frozen cell pellet was resuspended in homogenization buffer (50 mM TRIS, pH 8.0) at a concentration of 10-20 g DCW L ${ }^{-1}$. Factor of wet cell weight (WCW) to DCW was previously determined as $3.89 \pm 0.21(n=3)$. Homogenization was done at 1500 bar with 3 passages on a PandaPLUS 2000 (GEA Mechanical Equipment, Parma, Italy), which was shown to be sufficient for complete cell disruption [33]. Afterwards, the homogenized suspension was centrifuged at $15,650 \mathrm{~g}$ for $20 \mathrm{~min}$ at $4{ }^{\circ} \mathrm{C}$ and the supernatant was discarded. The pellet was washed, centrifuged, and resuspended with deionized water at a concentration of $100 \mathrm{~g} \mathrm{WCW} \mathrm{L}^{-1}$ twice to remove host cell proteins from the IB pellet. To resuspend the pellet properly, a T-10 basic Ultra-Turrax (IKA, Staufen, Germany) was used at power level 5 for 30-60 s. After centrifugation, samples of the supernatant from the washing steps were taken for determination of total and target protein loss values. The washed IBs were stored at $-20{ }^{\circ} \mathrm{C}$.

\section{Solubilization of IBs}

Solubilization of IBs was done with solubilisation buffer (0.05 M TRIS, 2 M Urea, pH 12) at a concentration of $100 \mathrm{~g}$ wet weight $\mathrm{L}^{-1}$ similar to examples from literature $[34,35]$. The T-10 basic Ultra-Turrax was used at power level 5 for 30-60 s to suspend the IBs in the buffer. The solution was shaken at $80 \mathrm{rpm}$ at room temperature for $1 \mathrm{~h}$. The solution was centrifuged at $15,650 \mathrm{~g}$ at $4{ }^{\circ} \mathrm{C}$ for 20 min to sediment insoluble artefacts. Prior to the refolding, a small amount of IBs from the respective cultivation was solubilised and analysed via size exclusion chromatography (SEC) HPLC to determine protein concentration, which was later used to determine the necessary solubilisate volume for the refolding. The solution, containing solubilised IBs, was called solubilisate. The final solubilisate with known protein concentration was used for refolding immediately.

\section{Refolding}

Refolding was done in sterile $50 \mathrm{~mL}$ tubes. The refolding buffer only contained $8 \% \mathrm{v} / \mathrm{v}$ glycerol to preserve protein stability and prevent protein aggregation [36]. No additives were further used in the refolding buffer, beside of residual urea and TRIS from the solubilisate addition. Prior optimization studies have shown that the very mild refolding buffer (deionized water and $8 \% \mathrm{v} / \mathrm{v}$ glycerol) was sufficiently working like TRIS containing buffers with various additives. Around $0.5 \mathrm{~mL}$ solubilisate and $1.0 \mathrm{~mL}$ solubilisation buffer were mixed and added to $38.5 \mathrm{~mL}$ precooled refolding buffer. Refolding was done in a total volume of $40 \mathrm{~mL}$ at $7{ }^{\circ} \mathrm{C}$ under light shaking at a protein concentration of around $0.5 \mathrm{~g} \mathrm{~L}^{-1}$. Samples were taken after $180 \mathrm{~min}$ and were snap-frozen in liquid nitrogen to prevent degradation and to preserve the refolding state until further analysis. Refolding samples were then stored at $-20^{\circ} \mathrm{C}$ and analysed on HPLC within a week.

\section{Sample analysis}

During the course of the study, we observed that protein concentration of the samples was more accurate and reproducible when analysed by SEC HPLC instead of Bradford assay. Due to a non-existing standard of the target protein, a BSA standard was used for the determination of protein concentration. Chromatographic analysis was done at $280 \mathrm{~nm}$ with the software Chromeleon 7 Chromatography Data System Version 7.2 SR5 (Thermo Scientific, Vienna, Austria).

\section{Sample preparation}

Samples of solubilisate and refolded target protein were prepared by the following: Snap-frozen samples were directly thawed for $3 \mathrm{~min}$ at $37^{\circ} \mathrm{C}$ in a heating block and inverted carefully six times. Then, they were centrifuged for $2.5 \mathrm{~min}$ at $14,800 \mathrm{rpm}$ in a micro centrifuge. $500 \mu \mathrm{L}$ of the sample were transferred into an HPLC glass vial and measured immediately. 


\section{HPLC analysis of solubilisate samples}

Solubilisate samples were measured with a BioBasic SEC300 size exclusion column (Thermo Scientific, Vienna, Austria). The mobile phase was $4 \mathrm{M}$ guanidine hydrochloride (Gdn-HCl), $0.05 \mathrm{M}$ Bis-TRIS, $0.15 \mathrm{M} \mathrm{NaCl}$, and pH 6.8. The injection volume was $10 \mu \mathrm{L}$ and an isocratic flow of $0.1 \mathrm{~mL} \mathrm{~min}^{-1}$ was used for $30 \mathrm{~min}$. All buffers were sterile filtrated and sonicated. Total areas and target peak areas were identified in the chromatograms to determine total and target protein concentration with a BSA standard calibration. BSA standards were prepared in solubilisation buffer to a concentration range of $1-100 \mathrm{~g} \mathrm{~L}^{-1}$.

\section{HPLC analysis of refolding samples}

Refolding samples were measured with an MAbPac ${ }^{\mathrm{TM}}$ SEC-1 size exclusion column $4 \times 300 \mathrm{~mm}$ length (Thermo Scientific, Vienna, Austria). The mobile phase was $0.1 \mathrm{M}$ sodium dihydrogen phosphate, $0.3 \mathrm{M} \mathrm{NaCl}, \mathrm{pH}$ 6.8. The injection volume was $10 \mu \mathrm{L}$ and an isocratic flow of $0.150 \mathrm{~mL} \mathrm{~min}^{-1}$ was used for $40 \mathrm{~min}$. All buffers were sterile filtrated and sonicated. Total areas and target peak areas were identified in the chromatograms to determine total and target protein concentration with a BSA standard calibration. BSA standards were prepared in refolding buffer to a concentration range from 0.1 to $5.0 \mathrm{~g} \mathrm{~L}^{-1}$.

\section{Determination of specific product titer}

The product titer was not defined as the amount of IBs per biomass, but as the amount of soluble target protein in the solubilisate, which was derived from a defined amount of IBs and biomass. For the specific product titer determination, the DSP protocol was carried out until the solubilisation step. The specific amount of target protein was determined according to formula (3):

$$
\begin{aligned}
& \text { Specific product titer }\left[\frac{\mathrm{mg} \text { target }}{\mathrm{g} \text { WCW }}\right] \\
& =\frac{\text { solu. buffer }[\mathrm{L}] \times \operatorname{target} \text { peak }\left[\frac{\mathrm{g}}{\mathrm{L}}\right]}{\text { weighed biomass in WCW prior to cell disruption }[\mathrm{g}]} \\
& \times 1000,
\end{aligned}
$$

where solu. buffer $=$ amount of solubilisation buffer used to solubilise IBs at a concentration of $100 \mathrm{~g} \mathrm{~L}^{-1}$.

\section{Determination of refolding yield}

Areas under the curve of each peak were used to calculate the protein concentration and refolding yield was calculated with formula (4):
Refolding yield $[\%]=\frac{\text { target peak in refolding }[\mathrm{g}]}{\text { target peak in solubilisate }[\mathrm{g}]} \times 100$.

\section{Results}

\section{Process reproducibility}

The impact technical failures in the USP can only be investigated properly, if the process is understood and under control. Therefore, we performed four cultivations $(\mathrm{C} 1-\mathrm{C} 4)$ to test for process reproducibility in the USP and DSP. These cultivations represented the standard process for the production of our target protein as IB. Furthermore, the IBs of the final biomass underwent a classical IB DSP down to the final refolding step. Based on the results, we were able to understand the variance of each unit operation or phase, which was given by the absolute average error $(\Theta)$ (Table 3 ). The USP and DSP of our IB production process was generally reproducible in regards to the final biomasses and the physiological parameters $\left(\mu_{\mathrm{max}}, q_{\mathrm{s}, \mathrm{Glc}}, Y_{\mathrm{X} / \mathrm{S}}, Y_{\mathrm{CO}_{2} / \mathrm{S}}\right)$ in the USP (see Fig. S1 for exemplary process and physiology data of cultivation $\mathrm{C} 1$ ). The high $\Theta$ for the $Y_{\mathrm{X} / \mathrm{S}}$ in the induction phase was attributed to the human interaction during biomass determination. Furthermore, also the DSP yielded comparable results between the different IBs. However, we encountered relatively high standard deviations for each parameter in the DSP and, therefore, also for the specific product titer. Although IB processing was done carefully, we assumed that the deviations could be also attributed to the required human interaction in each laboratory scale DSP unit operation. Nevertheless, after the IB wash, we calculated that the final biomass consisted to $30 \%$ of IBs, which underlined that our induction parameters were chosen accurately to produce high amounts of intracellular IBs. The final refolding process resulted in comparable amounts of target protein.

\section{Introduction of technical failures in the induction phase}

In cultivation $\mathrm{C} 6$ and $\mathrm{C} 7$, the technical failures "failure in temperature control" and "failure in $\mathrm{pH}$ control" were simulated by stopping the responsible control system of the respective bioreactors for approximately $1 \mathrm{~h}$. We found a higher DCW at the end of the cultivation in C5; no differences were found to the reproducibility runs in the USP and DSP. The higher DCW resulted from a higher starting DCW at the start of the induction phase, because the noninduced fed-batch ran approximately $30 \mathrm{~min}$ longer (see Fig. S2, Fig. S3, and Fig. S4 for process and physiology data of cultivation C5, C6, and C7). In the USP, the loss 
Table 3 Results for the reproducibility runs in the upstream and downstream process

\begin{tabular}{|c|c|c|c|c|c|}
\hline & $\mathrm{C} 1$ & $\mathrm{C} 2$ & C3 & $\mathrm{C} 4$ & $\Theta[\%]$ \\
\hline \multicolumn{6}{|l|}{ USP } \\
\hline \multicolumn{6}{|l|}{ Batch phase } \\
\hline $\mathrm{DCW}_{\text {End }}\left[\mathrm{g} \mathrm{L}^{-1}\right]$ & $8.8 \pm 0.9$ & $9.8 \pm 0.1$ & $9.2 \pm 0.1$ & $9.8 \pm 0.1$ & 4.3 \\
\hline$\mu_{\max }\left[\mathrm{h}^{-1}\right]$ & 0.55 & 0.52 & 0.56 & 0.54 & n.a. \\
\hline$Y_{\mathrm{X} / \mathrm{S}}\left[\mathrm{Cmol} \mathrm{\textrm {Cmol } ^ { - 1 } ]}\right.$ & $0.45 \pm 0.20$ & $0.47 \pm 0.11$ & $0.46 \pm 0.03$ & $0.50 \pm 0.06$ & 3.0 \\
\hline$Y_{\mathrm{CO}_{2} / \mathrm{S}}\left[\mathrm{Cmol} \mathrm{Cmol}^{-1}\right]$ & $0.36 \pm 0.01$ & $0.36 \pm 0.00$ & $0.37 \pm 0.01$ & $0.38 \pm 0.01$ & 8.2 \\
\hline C-balance $\left[\mathrm{Cmol} \mathrm{Cmol}^{-1}\right]$ & $0.82 \pm 0.21$ & $0.86 \pm 0.12$ & $0.84 \pm 0.05$ & $0.89 \pm 0.07$ & 2.6 \\
\hline \multicolumn{6}{|l|}{ Non-induced fed-batch phase } \\
\hline $\mathrm{DCW}_{\text {End }}\left[\mathrm{g} \mathrm{L}^{-1}\right]$ & $32.6 \pm 0.2$ & $35.5 \pm 0.1$ & $33.6 \pm 0.4$ & $33.6 \pm 0.7$ & 2.5 \\
\hline$q_{\mathrm{s}, \mathrm{Glc}}\left[\mathrm{g} \mathrm{g}^{-1} \mathrm{~h}^{-1}\right]$ & $0.20 \pm 0.00$ & $0.22 \pm 0.00$ & $0.23 \pm 0.00$ & $0.22 \pm 0.00$ & 4.0 \\
\hline$Y_{\mathrm{X} / \mathrm{S}}\left[\mathrm{Cmol} \mathrm{Cmol}^{-1}\right]$ & $0.53 \pm 0.14$ & $0.47 \pm 0.16$ & $0.45 \pm 0.09$ & $0.45 \pm 0.15$ & 5.6 \\
\hline$Y_{\mathrm{CO}_{2} / \mathrm{S}}\left[\mathrm{Cmol} \mathrm{Cmol}^{-1}\right]$ & $0.52 \pm 0.01$ & $0.44 \pm 0.00$ & $0.44 \pm 0.00$ & $0.42 \pm 0.00$ & 7.1 \\
\hline C-balance $\left[\mathrm{Cmol} \mathrm{Cmol}^{-1}\right]$ & $1.05 \pm 0.14$ & $0.93 \pm 0.17$ & $0.89 \pm 0.09$ & $0.88 \pm 0.15$ & 6.0 \\
\hline \multicolumn{6}{|l|}{ Induction phase } \\
\hline IPTG concentration $[\mathrm{mM}]$ & 1.0 & 1.0 & 1.0 & 1.0 & n.a. \\
\hline Duration [h] & 8.4 & 8.4 & 8.4 & 8.4 & n.a. \\
\hline $\mathrm{DCW}_{\text {End }}\left[\mathrm{g} \mathrm{L}^{-1}\right]$ & $42.5 \pm 0.1$ & $47.5 \pm 0.9$ & $44.8 \pm 0.1$ & $44.0 \pm 0.8$ & 3.2 \\
\hline$q_{\mathrm{s}, \mathrm{Glc}}\left[\mathrm{g} \mathrm{g}^{-1} \mathrm{~h}^{-1}\right]$ & $0.21 \pm 0.00$ & $0.20 \pm 0.00$ & $0.22 \pm 0.00$ & $0.24 \pm 0.00$ & 4.6 \\
\hline$Y_{\mathrm{X} / \mathrm{S}}\left[\mathrm{Cmol} \mathrm{Cmol}^{-1}\right]$ & $0.25 \pm 0.11$ & $0.40 \pm 0.11$ & $0.35 \pm 0.03$ & $0.24 \pm 0.09$ & 21.1 \\
\hline$Y_{\mathrm{CO}_{2} / \mathrm{s}}\left[\mathrm{Cmol} \mathrm{Cmol}^{-1}\right]$ & $0.52 \pm 0.00$ & $0.53 \pm 0.01$ & $0.51 \pm 0.00$ & $0.54 \pm 0.00$ & 1.9 \\
\hline C-balance $\left[\mathrm{Cmol} \mathrm{Cmol}{ }^{-1}\right]$ & $0.82 \pm 0.11$ & $1.03 \pm 0.12$ & $0.91 \pm 0.04$ & $0.82 \pm 0.10$ & 8.4 \\
\hline Specific product titer $\left[\mathrm{mg} \mathrm{g}^{-1} \mathrm{WCW}\right]$ & $57 \pm 9$ & $67 \pm 0$ & $73 \pm 15$ & $75 \pm 5$ & 8.8 \\
\hline \multicolumn{6}{|l|}{ DSP } \\
\hline \multicolumn{6}{|l|}{ IB wash } \\
\hline Ratio target/total [-] & $0.11 \pm 0.02$ & $0.10 \pm 0.01$ & $0.10 \pm 0.02$ & $0.08 \pm 0.02$ & 9.0 \\
\hline Ratio IB/BM [-] & $0.28 \pm 0.01$ & $0.29 \pm 0.01$ & $0.29 \pm 0.02$ & $0.29 \pm 0.04$ & 1.5 \\
\hline \multicolumn{6}{|l|}{ IB solubilisation } \\
\hline Duration $[\mathrm{h}]$ & 1 & 1 & 1 & 1 & n.a. \\
\hline Ratio target/total [-] & $0.49 \pm 0.07$ & $0.58 \pm 0.05$ & $0.51 \pm 0.11$ & $0.67 \pm 0.07$ & 11.1 \\
\hline \multicolumn{6}{|l|}{ IB refolding } \\
\hline Duration [h] & 3 & 3 & 3 & 3 & n.a. \\
\hline Refolding yield [\%] & $30 \pm 6$ & $31 \pm 7$ & $31 \pm 6$ & $33 \pm 1$ & 2.4 \\
\hline Ratio target/total [-] & $0.21 \pm 0.02$ & $0.24 \pm 0.03$ & $0.23 \pm 0.02$ & $0.25 \pm 0.04$ & 5.4 \\
\hline
\end{tabular}

Results are given for each phase in the upstream process. Batch phase for initial biomass accumulation, non-induced fed-batch (fed-batch) phase, and induced (induction) phase. Dry cell weight measurement errors were derived from triplicate measurements. Standard deviations from physiological parameters were derived from error propagation. Standard deviations from the specific product titer and the downstream process parameters were derived from duplicate processing and measuring. Shown downstream process focused on the inclusion body washing procedures (IB wash), the inclusion body solubilisation procedure (IB solubilisation), and the final refolding process (IB refolding). The absolute average error $(\Theta)$ was determined to gain insight on variation of the process parameters for each phase and unit operation

n.a. not applicable

of temperature control in C6 was followed by an immediate temperature increase from 30 to $40.4{ }^{\circ} \mathrm{C}$ at a rate of $0.17^{\circ} \mathrm{C} \mathrm{min}^{-1}$. Together with the temperature increase, the $\mathrm{dO}_{2}$ decreased and the offgas $\mathrm{CO}_{2}$ increased, respectively. During the deviation phase and at the end of the regeneration phase (=end of cultivation), no metabolites or glucose accumulated (Fig. 1). However, clear foam formation was visible during the deviation phase, which stopped when the temperature control was activated again. The physiological parameters did not show an irreversible change in cellular performance compared to the reference. Although foam formation might result from cell lysis, no additional indications, like a decreased DCW or an elevated absorption in $260 \mathrm{~nm}$, were found (Table 4). It was rather believed that foam formation resulted from denatured extracellular protein and a decreased gas solubility (Henry's law) through the increased temperature. The specific product titer was not affected, but, more interestingly, it had a rather positive 

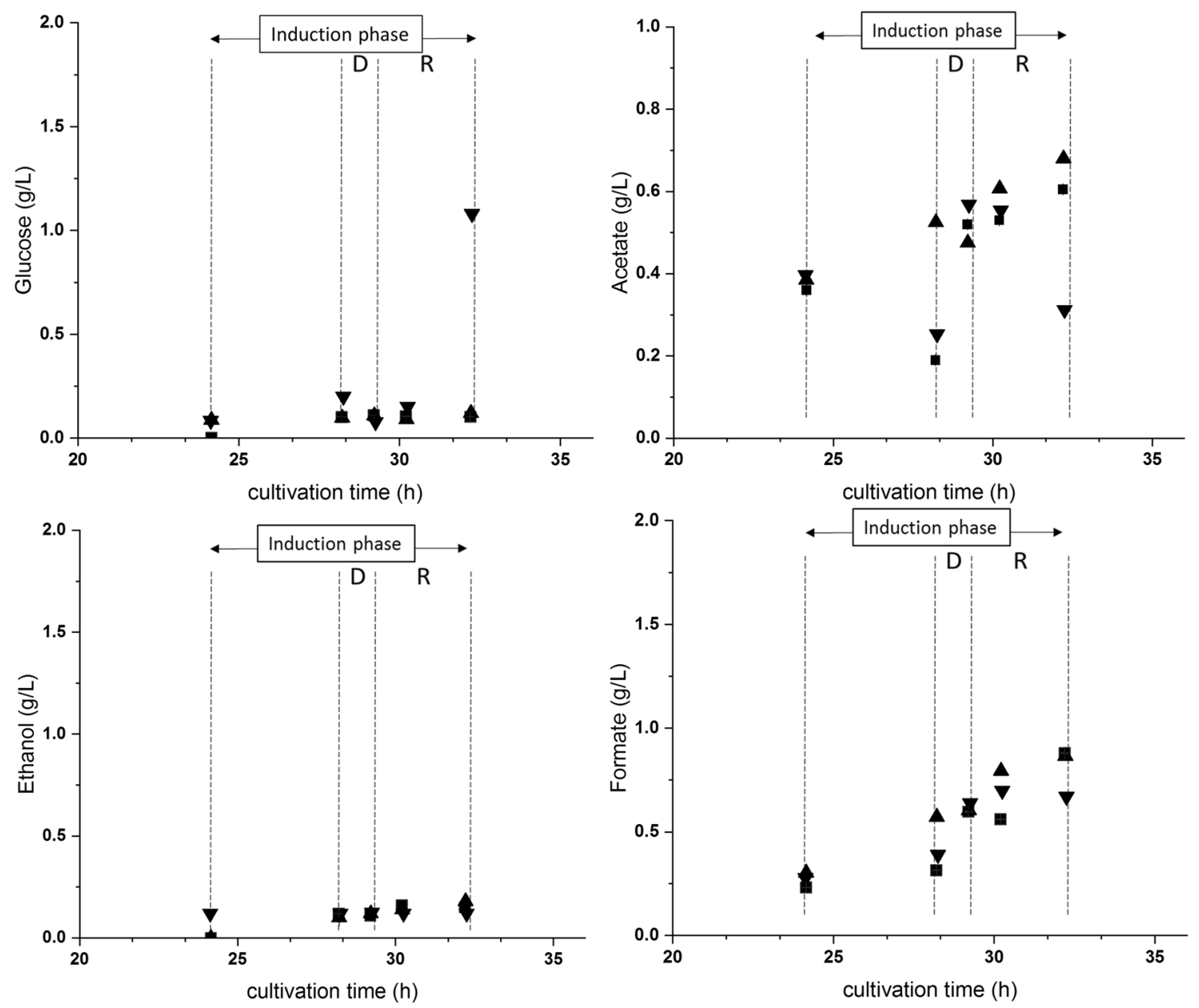

Fig. 1 Monitoring of glucose and metabolite (ethanol, formate, and acetate) content in the cultivation broths of C5-C7. (Filled square) C5-reference run; (filled triangle) C6-failure in temperature con-

impact on the following DSP (Fig. 2). We found less target protein in the IB wash solution than in the reference and the refolding yield of $47 \pm 5 \%$ was clearly elevated.

In cultivation $\mathrm{C} 7$, the loss of $\mathrm{pH}$ control led to a decrease from $\mathrm{pH} 7.2$ to 6.7 of a rate of $0.008 \mathrm{~min}^{-1}$. Again, no accumulation of metabolites or glucose was seen during the deviation phase. However, we observed an elevated absorption in $260 \mathrm{~nm}$ and an increased glucose content of $1 \mathrm{~g} \mathrm{~L}^{-1}$ in the culture broth at the end of the regeneration phase (=end of cultivation) (Fig. 1). Although the increased glucose content was probably related to a decreased cellular performance, no decreased DCW or decreased physiological parameters were found. The specific product titer and the DSP results showed no difference to the reference (Fig. 2). Therefore, the short inability to control the temperature or the $\mathrm{pH}$ seemed to have no negative impact on the USP and the DSP of the IB process.

trol; (filled inverted triangle) $\mathrm{C} 7$-failure in $\mathrm{pH}$ control. Induction phase is shown. Deviation phase is shown as $\mathrm{D}$ and regeneration phase as $\mathrm{R}$. The induction phase included the phases D and R

\section{Introduction of technical failures at the end of induction phase}

In the final stage of the induction phase, substrate depletion, due to an empty feed tank or overfeeding, due to the strains decreasing ability for substrate uptake, can occur. In cultivations $\mathrm{C} 9$ and $\mathrm{C} 10$, the technical failures "interruption of feeding" and "overfeeding" were simulated by stopping the responsible pump or increasing the feed addition for the respective bioreactors for approximately $1 \mathrm{~h}$ (see Fig. S5, Fig. S6, and Fig. S7 for process and physiology data of cultivation $\mathrm{C} 8, \mathrm{C} 9$, and $\mathrm{C} 10)$. Subsequent to the interruption of feeding in $\mathrm{C} 9$, the $\mathrm{dO}_{2}$ indicated the immediate depletion of glucose. The cellular activity decreased and the $\mathrm{pH}$ increased as it was expected upon substrate depletion, because organic acids were most likely taken up. The $\mathrm{pH}$ increase was maintained by acid addition in the deviation phase. After standard process conditions were again present, the process parameters stabilized quickly. However, 
Table 4 Results for the cultivations $\mathrm{C} 5-\mathrm{C} 7$

\begin{tabular}{|c|c|c|c|}
\hline & C5 (reference) & C6 ( $T$ failure $)$ & $\mathrm{C} 7$ (pH failure) \\
\hline \multicolumn{4}{|l|}{ Regeneration phase } \\
\hline Deviation phase $[\mathrm{h}]$ & 0 & 1.0 & 1.0 \\
\hline $\mathrm{DCW}_{\text {End }}\left[\mathrm{g} \mathrm{L}^{-1}\right]$ & $49.0 \pm 0.2$ & $48.9 \pm 0.2$ & $50.7 \pm 0.4$ \\
\hline Glucose $\left[\mathrm{g} \mathrm{L}^{-1}\right]$ & $0.20 \pm 0.00$ & $0.25 \pm 0.00$ & $1.08 \pm 0.00$ \\
\hline Acetate $\left[\mathrm{g} \mathrm{L}^{-1}\right]$ & $0.61 \pm 0.00$ & $0.68 \pm 0.00$ & $0.32 \pm 0.00$ \\
\hline Formate $\left[\mathrm{g} \mathrm{L}^{-1}\right]$ & $0.88 \pm 0.00$ & $0.87 \pm 0.00$ & $0.67 \pm 0.00$ \\
\hline Ethanol $\left[\mathrm{g} \mathrm{L}^{-1}\right]$ & $0.15 \pm 0.00$ & $0.18 \pm 0.00$ & $0.12 \pm 0.00$ \\
\hline A260 [AU] & $20.8 \pm 0.1$ & $20.8 \pm 0.4$ & $22.8 \pm 0.0$ \\
\hline$q_{\mathrm{s}}\left[\mathrm{g} \mathrm{g}^{-1} \mathrm{~h}^{-1}\right]$ & $0.22 \pm 0.01$ & $0.21 \pm 0.01$ & $0.21 \pm 0.00$ \\
\hline$Y_{\mathrm{X} / \mathrm{S}}\left[\mathrm{Cmol} \mathrm{\textrm {Cmol } ^ { - 1 } ]}\right.$ & $0.38 \pm 0.07$ & $0.34 \pm 0.08$ & $0.25 \pm 010$ \\
\hline$Y_{\mathrm{CO}_{2} / \mathrm{S}}\left[\mathrm{Cmol} \mathrm{\textrm {Cmol } ^ { - 1 } ]}\right.$ & $0.51 \pm 0.01$ & $0.53 \pm 0.01$ & $0.53 \pm 0.01$ \\
\hline $\mathrm{C}$-balance $\left[\mathrm{Cmol} \mathrm{Cmol}^{-1}\right]$ & $0.92 \pm 0.07$ & $0.92 \pm 0.08$ & $0.91 \pm 0.11$ \\
\hline Specific product titer $\left[\mathrm{mg} \mathrm{g}^{-1} \mathrm{WCW}\right]$ & $55.7 \pm 3.5$ & $60.3 \pm 9.6$ & $52.6 \pm 3.5$ \\
\hline \multicolumn{4}{|l|}{ IB wash } \\
\hline Ratio target/total [-] & $0.12 \pm 0.01$ & $0.09 \pm 0.00$ & $0.11 \pm 0.01$ \\
\hline Ratio IB/BM [-] & $0.25 \pm 0.01$ & $0.25 \pm 0.01$ & $0.25 \pm 0.01$ \\
\hline \multicolumn{4}{|l|}{ IB solubilisation } \\
\hline Duration $[\mathrm{h}]$ & 1 & 1 & 1 \\
\hline Ratio target/total [-] & $0.58 \pm 0.01$ & $0.58 \pm 0.02$ & $0.54 \pm 0.06$ \\
\hline \multicolumn{4}{|l|}{ IB refolding } \\
\hline Duration [h] & 3 & 3 & 3 \\
\hline Refolding [\%] & $34 \pm 5$ & $47 \pm 5$ & $29 \pm 2$ \\
\hline Ratio target/total [-] & $0.18 \pm 0.01$ & $0.19 \pm 0.01$ & $0.19 \pm 0.01$ \\
\hline
\end{tabular}

Results are given for the regeneration phase in the upstream process, which followed the deviation phase. Dry cell weight measurement errors were derived from triplicate measurements. Standard deviations from physiological parameters were derived from error propagation. Standard deviations from the specific product titer and the downstream process parameters were derived from duplicate processing and measuring. Shown downstream process focused on the inclusion body washing procedures (IB wash), the inclusion body solubilisation procedure (IB solubilisation), and the final refolding process (IB refolding)

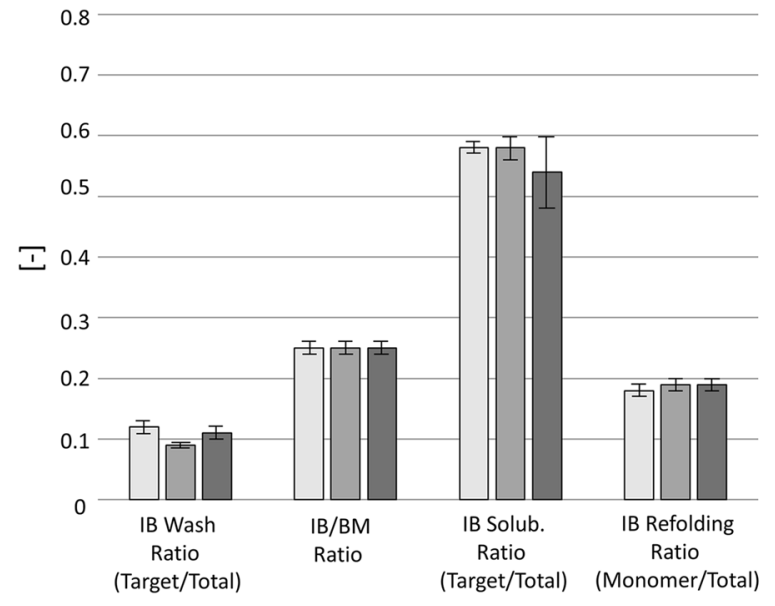

Fig. 2 Evaluation of inclusion body downstream processing from cultivations $\mathrm{C} 5-\mathrm{C} 7$. Bars from left to right show results from $\mathrm{C} 5-$ reference run, C6-failure in temperature control, and $\mathrm{C} 7$ - failure in $\mathrm{pH}$ control. On the left, the results of the inclusion body wash procedure, the measured ratio of inclusion body to biomass after the inclusion

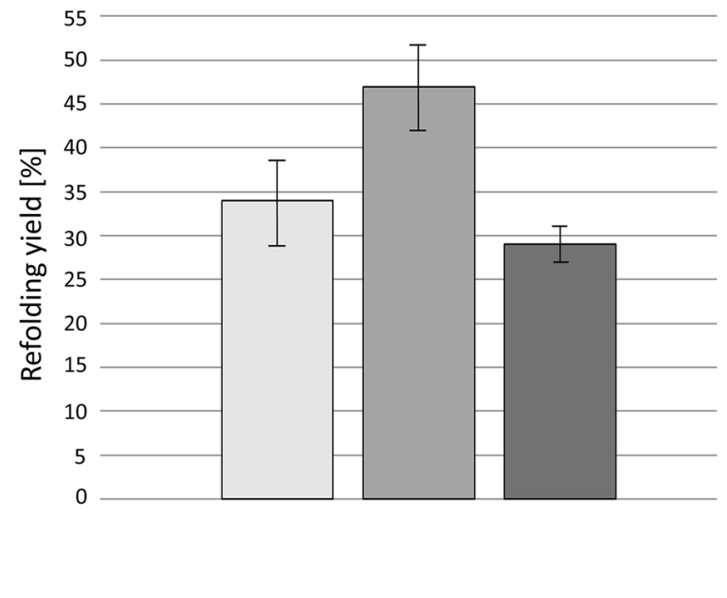

body wash, the purity of inclusion body solubilisation, and the purity of the inclusion body refolding procedure are shown. On the right, the final refolding yield after $180 \mathrm{~min}$ of refolding is shown. Error bars were derived from duplicates for all shown results 
we found a decreased $Y_{\mathrm{X} / \mathrm{S}}, Y_{\mathrm{CO}_{2} / \mathrm{s}}$ and C-balance during the regeneration phase compared to the reference (Table 5), but no accumulation of glucose or metabolites (Fig. 3). Together, these responses might highlight a metabolic switch towards substrate storage. In addition, neither the specific product titer nor the IB DSP was affected (Fig. 4).

The increase in feeding in cultivation $\mathrm{C} 10$ led to unexpected results. Although additional available substrate should be visible in increased cellular activity, the expected increase in offgas $\mathrm{CO}_{2}$ and decrease in $\mathrm{dO}_{2}$ was not found in the deviation phase. In addition, the physiological parameters were not affected during the deviation phase. Furthermore, the increase in feeding led to accumulation of glucose (Fig. 3). Furthermore, glucose accumulation proceeded during the regeneration phase (Table 5). It rather seemed that the cellular machinery was not able to cope with the additional substrate and was already running at its maximum specific substrate uptake rate $\left(q_{\mathrm{s}, \mathrm{Glc} \text {, max }}\right)$. Acetate accumulation, which is a clear indicator of overflow metabolism, was also not present during the deviation and regeneration phase. The increased feed addition led to no increase in the specific product titer or an impact on the IB DSP (Fig. 4). Therefore, feeding-related technical failures at the end of the induction phase did not seem to have a negative impact on the USP and DSP.

\section{Discussion}

The controlled introduction of technical failures revealed interesting aspects of the IB production chain in the USP and DSP. However, we have to highlight that we focused only on quantitative measurements like titer and purity and did not analyse the biological activity and CQAs of the antibody fragment. The initial evaluation of the whole process chain (C1-C4) was a valuable asset to determine the variability of each phase and unit operation. Almost all analysed parameters in the USP and DSP showed a $\Theta<10 \%$, and hence, we concluded that the presented process was reproducible. However, we did observe increased standard deviations for a variety of parameters, like the $Y_{\mathrm{X} / \mathrm{S}}$ and in the steps including IB processing, which was probably caused by human
Table 5 Results for the cultivations $\mathrm{C} 8-\mathrm{C} 10$

\begin{tabular}{|c|c|c|c|}
\hline & C8 (reference) & C9 (feed stop) & C10 (overfed) \\
\hline \multicolumn{4}{|l|}{ Regeneration phase } \\
\hline Deviation phase $[\mathrm{h}]$ & 0 & 1.4 & 1.4 \\
\hline $\mathrm{DCW}_{\text {End }}\left[\mathrm{g} \mathrm{L}^{-1}\right]$ & $44.7 \pm 0.2$ & $44.3 \pm 0.3$ & $45.2 \pm 0.1$ \\
\hline Glucose $\left[\mathrm{g} \mathrm{L}^{-1}\right]$ & $2.68 \pm 0.01$ & $0.82 \pm 0.00$ & $7.73 \pm 0.03$ \\
\hline Acetate $\left[\mathrm{g} \mathrm{L}^{-1}\right]$ & $0.28 \pm 0.00$ & $0.25 \pm 0.00$ & $0.26 \pm 0.00$ \\
\hline Formate $\left[\mathrm{g} \mathrm{L}^{-1}\right]$ & $1.32 \pm 0.00$ & $1.15 \pm 0.00$ & $1.21 \pm 0.00$ \\
\hline Ethanol $\left[\mathrm{g} \mathrm{L}^{-1}\right]$ & $0.51 \pm 0.02$ & $0.51 \pm 0.00$ & $0.22 \pm 0.00$ \\
\hline $\mathrm{A} 260[\mathrm{AU}]$ & $26.4 \pm 0.1$ & $26.6 \pm 0.4$ & $25.4 \pm 0.0$ \\
\hline$q_{\mathrm{s}}\left[\mathrm{g} \mathrm{g}^{-1} \mathrm{~h}^{-1}\right]$ & $0.19 \pm 0.00$ & $0.21 \pm 0.00$ & $0.17 \pm 0.00$ \\
\hline$Y_{\mathrm{X} / \mathrm{S}}\left[\mathrm{Cmol} \mathrm{\textrm {Cmol } ^ { - 1 } ]}\right.$ & $0.26 \pm 0.07$ & $0.15 \pm 0.03$ & $0.26 \pm 0.05$ \\
\hline$Y_{\mathrm{CO}_{2} / \mathrm{S}}\left[\mathrm{Cmol} \mathrm{Cmol}^{-1}\right]$ & $0.59 \pm 0.00$ & $0.47 \pm 0.00$ & $0.64 \pm 0.01$ \\
\hline C-balance $\left[\mathrm{Cmol} \mathrm{Cmol}{ }^{-1}\right]$ & $0.94 \pm 0.07$ & $0.63 \pm 0.04$ & $0.95 \pm 0.05$ \\
\hline Specific product titer $\left[\mathrm{mg} \mathrm{g}^{-1} \mathrm{WCW}\right]$ & $81.2 \pm 9.1$ & $83.7 \pm 3.7$ & $88.9 \pm 5.9$ \\
\hline \multicolumn{4}{|l|}{ IB wash } \\
\hline Ratio target/total [-] & $0.09 \pm 0.02$ & $0.09 \pm 0.01$ & $0.08 \pm 0.02$ \\
\hline Ratio IB/BM [-] & $0.36 \pm 0.01$ & $0.41 \pm 0.17$ & $0.40 \pm 0.05$ \\
\hline \multicolumn{4}{|l|}{ IB solubilisation } \\
\hline Duration [h] & 1 & 1 & 1 \\
\hline Ratio target/total [-] & $0.60 \pm 0.06$ & $0.53 \pm 0.04$ & $0.63 \pm 0.02$ \\
\hline \multicolumn{4}{|l|}{ IB refolding } \\
\hline Duration [h] & 3 & 3 & 3 \\
\hline Refolding [\%] & $29 \pm 5$ & $25 \pm 5$ & $34 \pm 1$ \\
\hline Ratio target/total [-] & $0.20 \pm 0.01$ & $0.18 \pm 0.01$ & $0.25 \pm 0.02$ \\
\hline
\end{tabular}

Results are given for the regeneration phase in the upstream process, which followed the deviation phase. Dry cell weight measurement errors were derived from triplicate measurements. Standard deviations from physiological parameters were derived from error propagation. Standard deviations from the specific product titer and the downstream process parameters were derived from duplicate processing and measuring. Shown downstream process focused on the inclusion body washing procedures (IB wash), the inclusion body solubilisation procedure (IB solubilisation), and the final refolding process (IB refolding) 

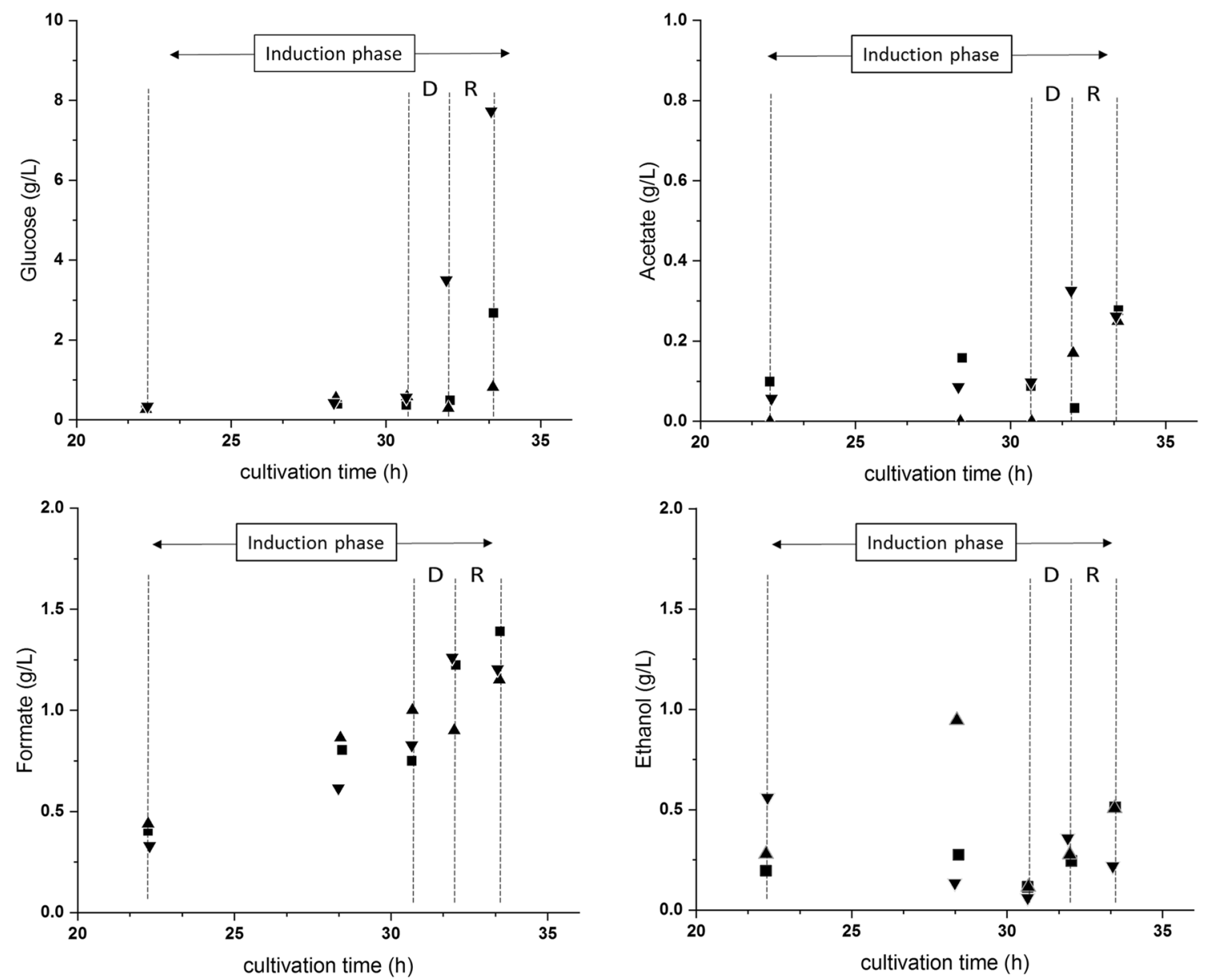

Fig. 3 Monitoring of glucose and metabolite (ethanol, formate, and acetate) content in the cultivation broths of $\mathrm{C} 8-\mathrm{C} 10$. (Filled square) C8-reference run; (filled triangle) C9-interruption of feed-

ing; (filled inverted triangle) $\mathrm{C} 10$-overfeeding. Induction phase is shown. Deviation phase is shown as D and regeneration phase as $\mathrm{R}$. The induction phase included the phases $\mathrm{D}$ and $\mathrm{R}$
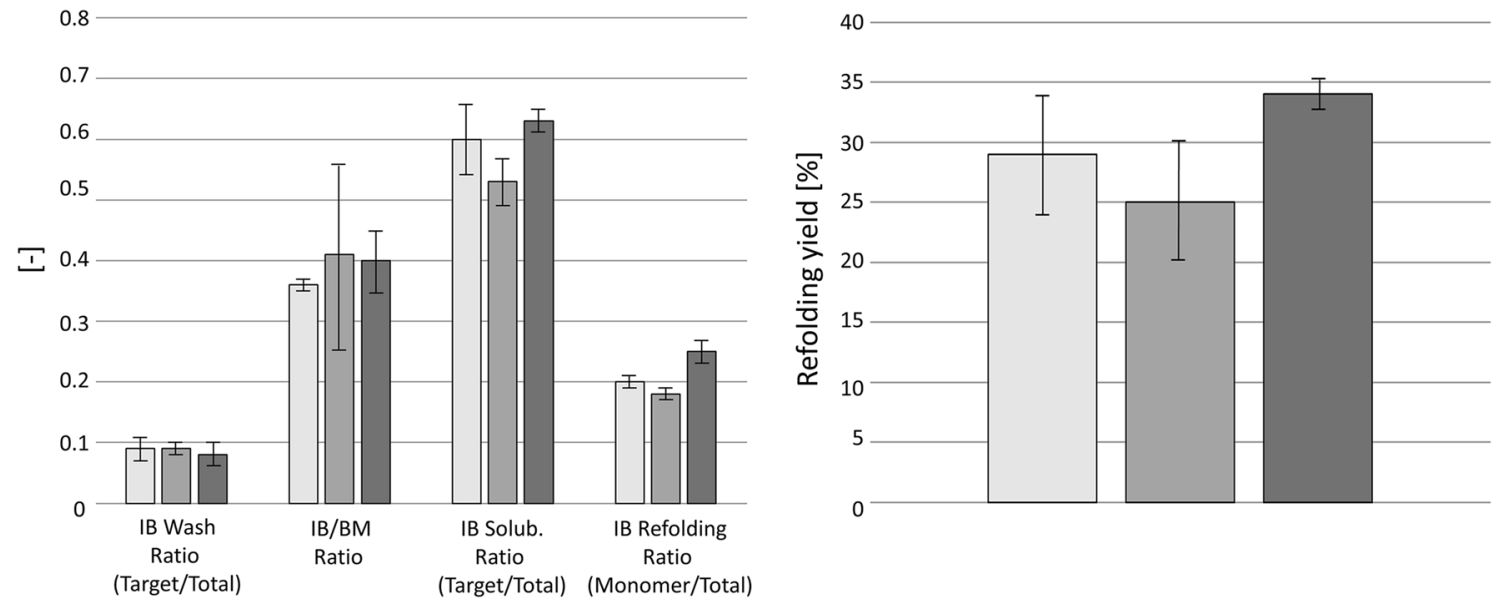

Fig. 4 Evaluation of inclusion body downstream processing from cultivations $\mathrm{C} 8-\mathrm{C} 10$. Bars from left to right show results from $\mathrm{C} 8-$ reference run, C9-interruption of feeding, and $\mathrm{C} 10$ - overfeeding. On the left, the results of the inclusion body wash procedure, the measured ratio of inclusion body to biomass after the inclusion body

wash, the purity of inclusion body solubilisation, and the purity of the inclusion body refolding procedure are shown. On the right, the final refolding yield after $180 \mathrm{~min}$ of refolding is shown. Error bars were derived from duplicates for all shown results 
interaction. This problem is known especially for the USP and is tackled by researchers through development for sampling automation and closed-loop process control (e.g., [37, 38]). In this study, IB processing was only possible through human interaction, due to the given sample sizes. However, the goal of this study was not process optimization, but generation of process knowledge. Nevertheless, the found IB content of around 30\% in the biomass stood in good agreement with recent findings in our research group. We have shown that the maximum intracellular IB size varied between 500 and $700 \mathrm{~nm}$ [16], which resembles a ratio around $30 \%$ of IB per cell given the rough E. coli size estimation of $2 \mu \mathrm{m}$. Furthermore, the basic and cheap refolding with glycerol as single additive in deionized water resulted in a refolding yield of around 30\% compared to 49\% [39] or $32.3 \%$ [35] for similar proteins in more complex buffers.

\section{Impact of technical failures on the USP}

Technical failures are critical in the phase of recombinant protein production, because they might change the cellular physiology and productivity. The four technical failures that we introduced in the induction phase resulted in varying responses. First, the loss in temperature control in cultivation C6 clearly increased the metabolic activity of the cells, which most likely also increased their $q_{\mathrm{s} \text {, Glc } \max }$ for a short time. However, given that a regeneration phase under normal conditions was added, no lasting negative impact on cellular physiology or product quantity was found. Recently, constant induction temperatures of $\sim 40^{\circ} \mathrm{C}$ were reported to reduce the IB titer and target protein activity $[15,28]$. The short shift in temperature had no negative impact on specific product titer, although it might be reasonable that longer shifts and higher temperatures lead to cell lysis and decrease in titer [15]. The loss of $\mathrm{pH}$ control in cultivation $\mathrm{C} 7$ neither led to foam formation nor clear changes in the $\mathrm{dO}_{2}$ or offgas values, but ongoing feed addition led to fast acidification of the culture broth to $\mathrm{pH} 6.7$ in approximately $1 \mathrm{~h}$. Again, no negative impact on the USP was found, including also the specific product titer compared to the reference, furthermore, recent results from our group highlighted a positive impact of $\mathrm{pH}<7.0$ on IB titer [15]. Although the $\mathrm{pH}$ decrease was only present for $1 \mathrm{~h}$ in our study, longer durations of $\mathrm{pH}$ decrease, especially below growth inhibiting conditions $\sim \mathrm{pH} 4.5$ [40], would certainly have negative effects on the USP. In the next cultivation series ( $\mathrm{C} 8-\mathrm{C} 10)$, we focused on prolonged induction times ( $>8$ to $10 \mathrm{~h}$ ) that are usually necessary to increase product yield. However, it is known that E. coli suffers from performance decreases, like decreased $\mu$ or $q_{\mathrm{s} \text {, Glc }}$, due to the metabolic stress upon recombinant protein production [32]. Therefore, we chose feedingrelated technical failures to analyse substrate accumulating conditions, but also substrate depleting conditions. Substrate depletion could result from wrong calculations for feed volume, defect pumps, or tubes for feed addition. In our study, the substrate depletion led to no accumulation of stressor metabolites (acetate and formate). Interestingly, the observed decrease in physiological parameters $\left(Y_{\mathrm{X} / \mathrm{S}}, Y_{\mathrm{CO}_{2} / \mathrm{S}}, \mathrm{C}\right.$-balance) and cell growth in the subsequent regeneration phase might be explained by recent findings regarding glycogen storage and consumption in E. coli [21]. It was reported that, upon depletion of substrate, $E$. coli cells switched their metabolism towards glycogen and acetate consumption for maintenance and vice versa, when substrate was available again. This would represent a rerouting of anabolism and catabolism and decrease $Y_{\mathrm{X} / \mathrm{S}}$ and $Y_{\mathrm{CO}_{2} / \mathrm{s}}$. However, no negative impact on specific product titer was found. In contrary to $\mathrm{C} 9$, cultivation $\mathrm{C} 10$ experienced an increased feed addition in the deviation phase. There, glucose accumulation was increasing and $\mathrm{dO}_{2}$ and offgas values did not represent increased substrate metabolization. This highlighted that the cellular machinery was already running at its maximum capacity $\left(q_{\mathrm{s}, \mathrm{Glc}, \max }\right)$ and was not able to metabolize additional substrate [32]. Similarly to cultivation C9, we could not observe a change in the specific product titer at the end of the cultivation, when compared to the reference. Summarizing, none of the presented technical failures should lead to process termination and batch loss, especially because no indications of cell lysis or decrease in specific product titer were found.

\section{Impact of technical failures on the DSP}

The integrated approach in this study to analyse not only the USP, but also the subsequent IB DSP resulted in some unforeseen results that might even improve future IB processes. First and most importantly, we could not show that the introduced technical failures had a negative impact on the DSP. Neither the IB purity nor the refolding step was negatively affected by the introduced technical failures in the USP. Therefore, we recommend using the IB containing biomass in each case. Furthermore, we later observed an increased refolding yield for IBs from cultivation C6, in which the temperature increased up to $40{ }^{\circ} \mathrm{C}$ for a short time. This finding was an interesting addition to recent results from our research group that showed a negative impact of increased temperatures on IB purity and titer [15]. The short increase in temperature in C7 did not negatively affect specific product titer or purity in our study, but we hypothesized that the short temperature increase led to an increased content of partially folded protein in the IBs, which aided the final refolding process. 


\section{Conclusion}

Here, we presented a reproducible IB production process chain for an antibody fragment, which yielded high IB content, high specific product titer, and a good refolding yield of $30 \%$ under simplest conditions. The introduction of technical failures proved that the IB production process chain shows great robustness in the DSP, which is most probably derived from the IB properties that protect the target protein from intra- and extracellular influences. From our results, we can conclude that the controlled introduction of technical failures is an easy method to validate theoretical considerations from risk analysis and that it provides the possibility to find process-boosting parameter shifts that would have been neglected. In our case, the short increase in temperature clearly increased the refolding yield. Most importantly, we could show that the occurrence of such technical failures does not necessarily affect the USP and DSP negatively. Therefore, one does not have to discard the cultivation broth, but rather proceed with the IB DSP. We hope that our study provides reference data for researchers in academia and industry that work with bacterial IBs. This study marks the beginning of a series of similar studies, which we will perform with soluble recombinant proteins in E. coli and more complex organisms in the future.

Acknowledgements Open access funding provided by TU Wien (TUW). The authors acknowledge the support of Thomas Frenzl during the bioreactor cultivations and the inclusion body processing. Further acknowledgement goes to TU Wien University Library for the financial support through its Open Access Funding Program.

\section{Compliance with ethical standards}

Conflict of interest The authors declare that they have no competing interests.

Ethical approval This study does not contain any studies with human participants or animals performed by any of the authors.

Open Access This article is distributed under the terms of the Creative Commons Attribution 4.0 International License (http://creativeco mmons.org/licenses/by/4.0/), which permits unrestricted use, distribution, and reproduction in any medium, provided you give appropriate credit to the original author(s) and the source, provide a link to the Creative Commons license, and indicate if changes were made.

\section{References}

1. FDA (2004) Guidance for Industry PAT - a framework for innovative pharmaceutical development, manufacturing, and quality assurance. U.S. Department of Health and Human Services, Food and Drug Administration. http://academy.gmp-compliance.org/ guidemgr/files/PAT-FDA-6419FNL.PDF. Accessed 20 Nov 2018
2. I.C.H. (2009) Q8(R2) Pharmaceutical development. https://www. ich.org/products/guidelines/quality/quality-single/article/pharm aceutical-development.html. Accessed 15 Nov 2018

3. I.C.H. (2005) Q9 Quality risk management. https://www.ich.org/ products/guidelines/quality/quality-single/article/quality-riskmanagement.html. Accessed 15 Nov 2018

4. I.C.H. (2008) Q10 Pharmaceutical quality system. https://www. ich.org/products/guidelines/quality/quality-single/article/pharm aceutical-quality-system.html. Accessed 15 Nov 2018

5. Rathore AS, Winkle H (2009) Quality by design for biopharmaceuticals. Nat Biotechnol 27:26. https://doi.org/10.1038/nbt01 09-26

6. Rathore AS, Bhambure R, Ghare V (2010) Process analytical technology (PAT) for biopharmaceutical products. Anal Bioanal Chem 398(1):137-154. https://doi.org/10.1007/s00216-010-3781-x

7. Rathore AS (2009) Roadmap for implementation of quality by design $(\mathrm{QbD})$ for biotechnology products. Trends Biotechnol 27(9):546-553. https://doi.org/10.1016/j.tibtech.2009.06.006

8. Ferreira AP, Tobyn M (2015) Multivariate analysis in the pharmaceutical industry: enabling process understanding and improvement in the PAT and QbD. Pharm Dev Technol 20(5):513-527. https://doi.org/10.3109/10837450.2014.898656

9. Gnoth S, Jenzsch M, Simutis R, Lubbert A (2008) Control of cultivation processes for recombinant protein production: a review. Bioprocess Biosyst Eng 31(1):21-39. https://doi.org/10.1007/ s00449-007-0163-7

10. Isermann $R$ (1984) Process fault detection based on modeling and estimation methods - a survey. Automatica 20(4):387-404. https ://doi.org/10.1016/0005-1098(84)90098-0

11. Qin SJ (2009) Data-driven fault detection and diagnosis for complex industrial processes. IFAC Proc Vol 42(8):1115-1125. https ://doi.org/10.3182/20090630-4-es-2003.00184

12. Villaverde A, Carrió MM (2003) Protein aggregation in recombinant bacteria: biological role of inclusion bodies. Biotechnol Lett 25:11

13. Alibolandi M, Mirzahoseini H (2011) Chemical assistance in refolding of bacterial inclusion bodies. Biochem Res Int 2011:631607. https://doi.org/10.1155/2011/631607

14. Samuelson JC (2011) Recent developments in difficult protein expression: a guide to E. coli strains, promoters, and relevant host mutations. In: Evans JTC, Xu M-Q (eds) Heterologous gene expression in E. coli: methods and protocols. Humana Press, Totowa, pp 195-209. https://doi.org/10.1007/978-1-61737 $-967-3 \_11$

15. Slouka C, Kopp J, Hutwimmer S, Strahammer M, Strohmer D, Eitenberger E, Schwaighofer A, Herwig C (2018) Custom made inclusion bodies: impact of classical process parameters and physiological parameters on inclusion body quality attributes. Microb Cell Fact 17(1):148. https://doi.org/10.1186/s12934-018-0997-5

16. Kopp J, Slouka C, Strohmer D, Kager J, Spadiut O, Herwig C (2018) Inclusion body bead size in E. coli controlled by physiological feeding. Microorganisms. https://doi.org/10.3390/micro organisms6040116

17. Wurm DJ, Quehenberger J, Mildner J, Eggenreich B, Slouka C, Schwaighofer A, Wieland K, Lendl B, Rajamanickam V, Herwig C, Spadiut O (2018) Teaching an old pET new tricks: tuning of inclusion body formation and properties by a mixed feed system in E. coli. Appl Microbiol Biotechnol 102(2):667-676. https://doi. org/10.1007/s00253-017-8641-6

18. Bylund F, Castan A, Mikkola R, Veide A, Larsson G (2000) Influence of scale-up on the quality of recombinant human growth hormone. Biotechnol Bioeng 69(2):119-128. https ://doi.org/10.1002/(SICI)1097-0290(20000720)69:2\%3c119 :AID-BIT1\%3e3.0.CO;2-9

19. Sandoval-Basurto EA, Gosset G, Bolivar F, Ramirez OT (2004) Culture of Escherichia coli under dissolved oxygen gradients 
simulated in a two-compartment scale-down system: metabolic response and production of recombinant protein. Biotechnol Bioeng 89(4):453-463. https://doi.org/10.1002/bit.20383

20. Luli GW, Strohl WR (1990) Comparison of growth, acetate production, and acetate inhibition of Escherichia coli strains in batch and fed-batch fermentations. Appl Environ Microbiol 56(4):1004-1011

21. Morin M, Ropers D, Cinquemani E, Portais JC, Enjalbert B, Cocaign-Bousquet M (2017) The Csr system regulates Escherichia coli fitness by controlling glycogen accumulation and energy levels. MBio. https://doi.org/10.1128/mBio.01628-17

22. Xu B, Jahic M, Enfors S-O (1999) Modeling of overflow metabolism in batch and fed-batch cultures of Escherichia coli. Biotechnol Prog 15:81-90

23. Presser KA, Ratkowsky DA, Ross T (1997) Modelling the growth rate of Escherichia coli as a function of $\mathrm{pH}$ and lactic acid concentration. Appl Environ Microbiol 63(6):2355-2360

24. Strandberg L, Enfors S-O (1991) Factors influencing inclusion body formation in the production of a fused protein in Escherichia coli. Appl Environ Microbiol 57(6):1669-1674

25. Peternel S, Jevsevar S, Bele M, Gaberc-Porekar V, Menart V (2008) New properties of inclusion bodies with implications for biotechnology. Biotechnol Appl Biochem 49:239-246. https://doi. org/10.1042/BA20070140

26. Wurm DJ, Marschall L, Sagmeister P, Herwig C, Spadiut O (2017) Simple monitoring of cell leakiness and viability in Escherichia coli bioprocesses-a case study. Eng Life Sci 17(6):598-604. https://doi.org/10.1002/elsc.201600204

27. Garcia-Fruitos E, Vazquez E, Diez-Gil C, Corchero JL, SerasFranzoso J, Ratera I, Veciana J, Villaverde A (2012) Bacterial inclusion bodies: making gold from waste. Trends Biotechnol 30(2):65-70. https://doi.org/10.1016/j.tibtech.2011.09.003

28. de Groot NS, Ventura S (2006) Effect of temperature on protein quality in bacterial inclusion bodies. FEBS Lett 580(27):64716476. https://doi.org/10.1016/j.febslet.2006.10.071

29. Hewitt CJ, Nienow AW (2007) The scale-up of microbial batch and fed-batch fermentation processes. Advances in applied microbiology, vol 62. Academic Press, pp 105-135. https://doi. org/10.1016/S0065-2164(07)62005-X

30. Bylund F, Collet E, Enfors SO, Larsson G (1998) Substrate gradient formation in the large-scale bioreactor lowers cell yield and increases by-product formation. Bioprocess Eng 18(3):171-180. https://doi.org/10.1007/s004490050427

31. DeLisa MP, Li J, Rao G, Weigand WA, Bentley WE (1999) Monitoring GFP-operon fusion protein expression during high cell density cultivation of Escherichia coli using an on-line optical sensor. Biotechnol Bioeng 65(1):54-64. https://doi.org/10.1002/(S ICI)1097-0290(19991 005)65:1\%3c54:AID-BIT7\%3e3.0.CO;2-R

32. Reichelt WN, Brillmann M, Thurrold P, Keil P, Fricke J, Herwig C (2017) Physiological capacities decline during induced bioprocesses leading to substrate accumulation. Biotechnol J. https ://doi.org/10.1002/biot.201600547

33. Eggenreich B, Rajamanickam V, Wurm DJ, Fricke J, Herwig C, Spadiut O (2017) A combination of HPLC and automated data analysis for monitoring the efficiency of high-pressure homogenization. Microb Cell Fact 16(1):134. https://doi.org/10.1186/s1293 4-017-0749-y

34. Singh A, Upadhyay V, Panda AK (2015) Solubilization and refolding of inclusion body proteins. In: García-Fruitós E (ed) Insoluble proteins: methods and protocols. Springer, New York, pp 283-291. https://doi.org/10.1007/978-1-4939-2205-5_15

35. Eggenreich B, Scholz E, Wurm DJ, Forster F, Spadiut O (2018) The production of a recombinant tandem single chain fragment variable capable of binding prolamins triggering celiac disease. BMC Biotechnol 18(1):30. https://doi.org/10.1186/s1289 6-018-0443-0

36. Cicerone MT, Soles CL (2004) Fast dynamics and stabilization of proteins: binary glasses of trehalose and glycerol. Biophys J 86(6):3836-3845. https://doi.org/10.1529/biophysj.103.035519

37. Kroll P, Hofer A, Ulonska S, Kager J, Herwig C (2017) Modelbased methods in the biopharmaceutical process lifecycle. Pharm Res 34:2596-2613. https://doi.org/10.1007/s11095-017-2308-y

38. Randek J, Mandenius CF (2018) On-line soft sensing in upstream bioprocessing. Crit Rev Biotechnol 38(1):106-121. https://doi. org/10.1080/07388551.2017.1312271

39. Sarker A, Rathore AS, Gupta RD (2019) Evaluation of scFv protein recovery from $E$. coli by in vitro refolding and mild solubilization process. Microb Cell Fact. https://doi.org/10.1186/s1293 4-019-1053-9

40. Presser KA, Ross T, Ratkowsky DA (1998) Modelling the growth limits (growth/no growth interface) of Escherichia coli as a function of temperature, $\mathrm{pH}$, lactic acid concentration, and water activity. Appl Environ Microbiol 64(5):1773-1779

Publisher's Note Springer Nature remains neutral with regard to jurisdictional claims in published maps and institutional affiliations. 